\title{
A escrita da história em Terra Sonâmbula de Mia Couto
}

\author{
The writing of history in the novel Sleepwalking Land, by Mia Couto
}

\author{
Flavia Renata Machado Paiani \\ espereaprimavera@bol.com.br \\ Doutoranda \\ Pontifícia Universidade Católica do Rio Grande do Sul \\ Rua Cel. Fernando Machado, 312/ 401 - Centro \\ 90010-320 - Porto Alegre - RS \\ Brasil
}

\section{Resumo}

O objetivo deste artigo é analisar de que forma o romance Terra Sonâmbula (1992), do escritor moçambicano Mia Couto, constitui-se como versão alternativa à historiografia a partir da própria história que o romance conta e sobre a qual ele silencia. Para tanto, considero que a narrativa coutiana assume um viés testemunhal, pois exprimiria a necessidade da "fala" por parte do autor após dezesseis anos de guerra civil em Moçambique (1976-1992). Assim, interessa-me saber a que leitor (que aqui substitui o ouvinte) o autor dirige sua narrativa para compreender os meandros da história que ele escreve, levando também em consideração a posição ocupada por Mia Couto na realidade de seu país. Percebo que o autor escreve sua versão da história a partir de três tendências interligadas: (i) o dever de memória; (ii) a construção de uma africanidade; e (iii) a perspectiva do futuro.

\section{Palavras-chave}

Escrita da história; Literatura; Mia Couto.

\begin{abstract}
The aim of this paper is to show how the novel Sleepwalking Land (1992), by the Mozambican writer Mia Couto, can be seen as an alternative version to historiography based on both the story that it actually tells and another one it silences about. For this, I consider Couto's narrative as a kind of eyewitness testimony, as the novel may be regarded as the result of the writer's need for "speaking out" after a sixteen-years long civil war (1976-1992) in his home country. I am thus interested in the reader (who replaces the listener here) to whom the author addresses his narrative in order to understand the intricacies of the story he writes. However, I'm also taking into account the position occupied by Mia Couto in the reality of his country. I realize that the author writes his version of history based on three interrelated trends: (i) the duty of memory, (ii) the construction of Africanness, and (iii) the perspective of future.
\end{abstract}

Keywords

History writing; Literature; Mia Couto.

Recebido em: 6/2/2013

Aprovado em: 3/6/2013 


\section{Preâmbulo: a historiografia e o romance}

O escritor moçambicano Mia Couto contava 37 anos (ou cerca disso) quando publicou, em 1992, seu primeiro romance, Terra Sonâmbula. Essa não era, contudo, a primeira vez que o autor publicava textos de sua autoria. Entre poemas, contos e crônicas, houve um caminho de quase dez anos até chegar ao romance. O estilo da escrita - que mescla prosa e poesia, a palavra falada e aquela reinventada - já estava presente nos seus contos dos anos 80 , assim como a temática da guerra civil em Moçambique, país onde nasceram o escritor e muitos de seus personagens.

No romance em questão, o autor alterna duas narrativas que se entrecruzam. Uma centra-se na história de um menino mulato, que havia perdido a memória e sido dado como morto no campo de deslocados onde se encontrava. Enquanto ele e outras crianças eram enterradas, um homem chamado Tuahir percebeu que o menino estava vivo e resolveu adotá-lo como "sobrinho" e dar-lhe o nome de Muidinga. A criança, ainda que desmemoriada, anseia encontrar os pais. A outra narrativa enfoca a história do jovem Kindzu, que vivia com os pais e o irmão caçula em uma aldeia até então pacífica, mas o irmão é raptado, o pai morre e a mãe enlouquece. Kindzu resolve, então, partir dali para juntar-se aos naparamas ${ }^{1}$, guerreiros que ele acreditava serem capazes de acabar com a guerra. Ele narra suas aventuras (e desventuras) em caderninhos, como se fossem diários. Muidinga, por sua vez, encontra esses cadernos depois que ele e Tuahir partem do campo de refugiados e buscam um lugar para se abrigarem.

A guerra torna-se, assim, o contexto espaço-temporal em que se desenrolam tanto a ação dos personagens quanto a escrita do autor. A publicação de Terra Sonâmbula ocorreu no final de dezesseis anos de guerra civil (19761992), deflagrada logo após a independência, em 1975. De um lado, havia a FRELIMO, sigla da Frente de Libertação de Moçambique, responsável pela guerrilha de libertação nacional entre 1964 e 1974 e pela presidência do país após a independência. De outro, havia a RENAMO, sigla da Resistência Nacional Moçambicana, movimento armado de viés conservador que visava à destituição da FRELIMO do poder face ao caráter socialista do governo.

Parte dessa história consta no livro A History of Mozambique (1995), ${ }^{2}$ de Malyn Newitt, professor de História do Departamento de Estudos Portugueses e Brasileiros na King's College, da Universidade de Londres. Em seu prefácio, Newitt começa por lembrar os 101 anos do surgimento do país dentro das fronteiras resultantes do tratado anglo-português de 1891. Moçambique surgia, assim, como "uma tentativa de dar sentido à história da região", abrangendo, em

\footnotetext{
${ }^{1}$ Segundo K. B. Wilson (1992, p. 560-561), os naparamas (também conhecidos como napramas, baramas ou paramas) surgiram entre o final de 1989 e o início de 1990 na fronteira entre Nampula e Zambézia (províncias situadas ao norte de Moçambique) e constituíram um movimento popular de caráter militar e religioso que se opunha à Resistência Nacional Moçambicana. Até então, a RENAMO detinha o "monopólio" dos poderes espirituais na guerra desencadeada contra a Frente de Libertação de Moçambique e utilizava os poderes que supostamente tinha para aterrorizar e subjugar a população. Os naparamas eram liderados por Manuel António, um homem de vinte e tantos anos, com pouca instrução formal, que declarava ter a missão divina de acabar com a guerra e libertar a nação. Para tanto, ele e seus seguidores lutavam com armas brancas, como as zagaias, e se diziam "vacinados" contra as balas.

2 O livro terminou de ser escrito em novembro de 1992, um mês após o fim da guerra civil em Moçambique.
} 
um único Estado colonial, os portos entre Cabo Delgado (no extremo nordeste do país) e a Baía de Maputo (antiga Delagoa Bay ou Baía da Lagoa, localizada ao sul) e suas respectivas áreas comerciais. A partilha da costa africana seguia, desse modo, a mesma lógica dos primeiros empreendimentos portugueses do século XVI. Era este, portanto, o sentido dado à história de Moçambique pelo colonialismo lusitano.

No entanto, cerca de setenta anos depois da criação do país, os filhos de Moçambique passaram a reivindicar não apenas o direito de serem agentes de sua própria história, mas também - acrescento - o direito de escreverem essa história. Durante os anos da luta armada de libertação nacional e mesmo após a independência, a FRELIMO procurou contar com jornalistas simpatizantes da causa (dentre eles, o jovem Mia Couto), encarregados de relatar a versão dos fatos diversa daqueles que comungavam com a ideologia do agonizante Terceiro Império Português. Vale lembrar que os principais quadros da FRELIMO eram compostos por moçambicanos educados no exterior, como o seu primeiro presidente, Eduardo Mondlane, que estudou na África do Sul, em Portugal e nos Estados Unidos, onde obteve o título de doutor em Sociologia.

Foram moçambicanos como Mondlane que elaboraram um projeto nacional para Moçambique a partir do qual falavam (e agiam) em nome do povo. Baseada em homens como eles, a história do país passou a estar atrelada à história do protagonismo da FRELIMO não apenas na luta anticolonial, mas, especialmente, no surgimento da nação. Recorro aqui à neoclássica concepção do cientista 206 político estadunidense Benedict Anderson sobre nação: "uma comunidade política imaginada - e imaginada como sendo intrinsecamente limitada e, ao mesmo tempo, soberana" (ANDERSON 2008, p. 32). Imaginada porque seus membros, em sua totalidade, jamais se conhecerão; limitada porque possui fronteiras finitas; soberana porque havia se libertado da dominação divina. No caso africano, a soberania de Moçambique ocorreu à medida que o país libertou-se da dominação metropolitana. Suas fronteiras, entretanto, permaneceram aquelas delimitadas pela antiga metrópole, assim como a língua portuguesa, alçada à língua oficial da então República Popular de Moçambique. O caráter popular da nascente república deveu-se à autodeclaração do caráter socialista do Estado. Essa orientação político-ideológica desencadeou, por seu turno, um movimento contrarrevolucionário capitaneado pela RENAMO, a qual, apoiada pela África do Sul, engendrou a guerra civil que perdurou por dezesseis anos.

Durante a guerra, o sentido de "comunidade" que define a nação havia sido esfacelado. A "profunda camaradagem horizontal" a que se refere Anderson (2008, p. 34) deu lugar a um sentimento semelhante ao de Tuahir: "Foi o que fez esta guerra: agora todos estamos sozinhos, mortos e vivos. Agora já não há país" (COUTO 2007, p. 153). Mia Couto foi perspicaz ao traduzir no romance a solidão que perpassava os moçambicanos, então unidos em torno de uma causa comum, expressa na luta pela independência do país. Mas o escritor não se refere somente aos vivos: há também os mortos, outrora re-presentificados nas narrativas, ritos e tradições que compunham uma história viva de Moçambique. A escrita, como lembra Newitt, raramente foi utilizada pela raça humana, no 
decurso da história, para registrar "quaisquer reflexões sobre a consciência de sua própria existência" (NEWITT 1995, p. 1). Kindzu, porém, registrou-a em seus caderninhos: escreveu não apenas sobre a cultura imaterial, os ensinamentos do nganga (adivinho-curandeiro), o ritual dos falecidos, mas também sobre o medo da morte, o desespero pelo esfacelamento familiar, o amor despertado pela linda Farida e toda a volúpia de sentimentos que permeia sua trajetória. Newitt, como historiador, circunscreveu a história da guerra civil a uma série de fatores de desintegração inseridos na longa história de Moçambique, acentuada pela fome, pela seca, pelo banditismo e pelos senhores da guerra durante os anos do conflito.

Sabemos, contudo, que a história não é escrita somente por historiadores. Mia Couto também a escreve a partir do silêncio de seus conterrâneos. É como se a guerra que se seguiu à independência e que terminou com a assinatura do Acordo Geral de Paz em quatro de outubro de 1992 apenas fosse recuperada nas páginas do romance do autor. Conforme assinala Couto, "ninguém se recorda de nada do que aconteceu. Foram 16 anos de guerra fratricida, um milhão de mortos, mas ninguém quer, hoje, relembrar este tempo de cinzas. Trata-se de uma estratégia de não despertar fantasmas mal resolvidos" (COUTO 2009a, p. 6).

Assim, os nomes do então presidente de Moçambique, Joaquim Chissano, e do presidente da RENAMO, Afonso Dhlakama, que assinaram o Acordo, podem ainda estar vivos na memória do povo, porém são as lembranças da guerra civil que têm sido sistematicamente apagadas das falas daqueles que a viveram. Mais do que uma política oficial de esquecimento, sobressai-se o fato de que "falar para fora" é uma noção estranha aos moçambicanos, assim como o é a noção de vingança (GRAYBILL 2004, p. 1125). Mia Couto, contudo, opta não apenas por falar, mas também por escrever, calcado nos silêncios da historiografia, no uso social do esquecimento e na produção de sua própria versão da história.

\section{A perspectiva do leitor-historiador}

É certo que Terra Sonâmbula surgiu como forma de Mia Couto exorcizar seus demônios interiores despertados pela guerra (COUTO 2009a, p. 6), logo a escrita literária funcionou, para o autor, como a necessidade contida no gesto testemunhal. Não se trata aqui de encarar a narrativa como verdadeira, mas de perceber nela o "desafio de estabelecer uma ponte com 'os outros', de conseguir resgatar o sobrevivente do sítio da outridade" (SELIGMANN-SILVA 2008, p. 66).

Partindo do pressuposto de que a narrativa do autor assume esse viés, interessa-me saber de que forma ela se constitui como versão alternativa à historiografia a partir da própria história que ela conta e daquela sobre a qual ela silencia. Para isso, questiono em que medida a posição ocupada por Couto na realidade moçambicana intervém na produção de sua obra, o que pressupõe uma breve digressão sobre o papel do leitor (-historiador) nessa relação.

O primeiro ponto sobre o qual vou discorrer é a influência ou não do contexto histórico nas preferências literárias (e acadêmico-científicas) do leitor (-crítico-pesquisador). Já no segundo ponto, pretendo analisar se a literatura funciona para o leitor como leitura de seu próprio eu, ao passo que, no terceiro, indago se o 
texto literário deve, ao contrário, apresentar-nos algo diferente de nosso próprio mundo. De modo geral, poderíamos afirmar que o leitor busca aquilo que ele considera "boa literatura". Sabemos, porém, que não é a vendagem expressiva de um livro nem a tradução para diversos idiomas (coisa que acontece com Mia Couto) que a caracterizaria como tal. Decerto, o modo coutiano de escrever e inventar palavras - algo, em parte, inspirado em Guimarães Rosa (um dos autores favoritos de Couto) - confere lirismo às situações cotidianamente difíceis de um país em guerra, como acontece em Terra Sonâmbula. Há um trecho do romance, por exemplo, que acho particularmente belo porque consegue expressar e entrecruzar, por meio de metáforas, três momentos avassaladores: a morte da baleia, a devastação do país e o sentimento de Kindzu.

Ouvíamos a baleia mas não lhe víamos. Até que, certa vez, desaguou na praia um desses mamíferos, enormão. Vinha morrer na areia. Respirava aos custos, como se puxasse o mundo nas suas costelas. A baleia moribundava, esgoniada. O povo acorreu para lhe tirar carnes, fatias e fatias de quilos. Ainda não morrera e já seus ossos brilhavam no sol. Agora, eu via o meu país como uma dessas baleias que vêm agonizar na praia. A morte nem sucedera e já as facas já lhe roubavam pedaços, cada um tentando o mais para si. Como se aquele fosse o último animal, a derradeira oportunidade de ganhar uma porção. De vez enquanto, me parecia ouvir ainda o suspirar do gigante, engolindo vaga após vaga, fazendo da esperança uma maré vazando. Afinal, nasci num tempo em que o tempo não acontece. A vida, amigos, já não me admite. Estou condenado a uma terra perpétua, como a baleia que esfalece na praia (COUTO 2007, p. 23).

É uma cena chocante, mas habilmente costurada pelo autor, em que a morte da baleia transita do plano social (a população faminta que escalpela o animal antes mesmo de ele morrer) para o político (a comparação da baleia agonizante ao país de Kindzu), e do político para o pessoal (o próprio Kindzu se vê como a baleia que morre na praia). No entanto, há quem possa achar, daqui a algum tempo, que a literatura de Couto seja, de fato, ruim; que toda a badalação que o autor recebe agora não corresponde à qualidade de sua obra. Por quê? Porque por mais que aspiremos à universalidade de uma obra, sua recepção, ao que parece, responde menos a uma suposta qualidade literária intrínseca que ao contexto histórico em que o leitor está inserido.

Recentemente, para ser exata, no dia 26 de janeiro de 2013, o jornal on-line porto-alegrense Sul 21 publicou uma lista dos cinquenta livros para morrer antes de ler, ou seja, uma lista das piores obras de autores brasileiros escolhidas por dez jurados entre críticos literários, ensaístas, poetas e romancistas. Qual não foi minha surpresa ao ver que constava o romance Um copo de cólera, de Raduan Nassar, publicado em 1978? A justificativa do jurado foi a seguinte: "Linguagem um tanto ultrapassada, alguma cólera e nenhum copo, que eu lembre" (SUL 21 2013). Raduan Nassar é conhecido pela sua habilidade ímpar de transformar a linguagem ordinária em prosa poética. Para o jurado, contudo, tratava-se de linguagem ultrapassada! Não tomemos, claro, como consenso a opinião do avaliador, porém permita-me notar o quão controversa é a questão 
daquilo que define uma "boa literatura" com o passar do tempo. Embora não seja meu objetivo encontrar uma definição apropriada para um conceito aparentemente difuso, importa-me esse "passar do tempo". Afinal, retomo, é o contexto histórico do leitor que parece incidir sobre a leitura do romance, qualificando-o certamente de acordo com critérios subjetivos, mas também com aqueles oriundos da sociedade em que o leitor-crítico está inserido. Assim, a popularidade ou não de uma obra, sua aclamação ou difamação entre a crítica literária e sua conversão em objeto de pesquisa acadêmica perpassam o contexto do leitor-crítico-pesquisador. A obra literária de Mia Couto faz parte atualmente do rol da pesquisa acadêmica brasileira, especialmente dos programas de pós-graduação em Letras, devido, em parte, ao interesse crescente pela cultura produzida na África, mas também ao talento atribuído ao autor. Ademais, ainda que em escala menor, o pano de fundo sócio-histórico desperta o interesse do historiador. Cito dois exemplos.

Um refere-se à tese de doutorado defendida em 2008 na Universidade de Brasília por Maria do Carmo Ferraz Tedesco. A partir dos romances de Mia Couto e de Paulina Chiziane, a historiadora pretende analisar "a reconfiguração das identidades moçambicanas" no contexto das transformações ocorridas no país nas duas últimas décadas. Ela procura entrever "as representações da sociedade" que os romances estabelecem, bem como a produção de sentidos na instauração de determinada imagem para "a identidade cultural coletiva". Ela explica que utiliza o romance como fonte histórica à medida que a literatura "é uma forma de representação do tempo vivido e que, tal como os estudos historiográficos, promove um ordenamento e uma configuração da experiência temporal dos homens" (TEDESCO 2008).

Da mesma forma, o segundo exemplo, a dissertação de Josilene Silva Campos defendida em 2009 na Universidade Federal de Goiás, pretende analisar "a reconfiguração da identidade nacional moçambicana" após a guerra civil - ou seja, após 1992. Para tanto, ela utiliza os romances de Mia Couto por entender que a literatura "é um tipo de conhecimento social formado no imaginário", que possibilita "um acesso privilegiado às sensibilidades de um tempo, às experiências vivenciadas e às discursividades construídas" (CAMPOS 2009).

Percebemos que os argumentos empregados por Josilene Campos não diferem daqueles já proferidos por Maria do Carmo Tedesco. Ambas não estão interessadas na "boa literatura" ou nos efeitos estéticos dos romances de Couto. Às historiadoras interessam os romances moçambicanos como representação social e cultural do contexto histórico do qual se originaram. O tema de suas pesquisas recai basicamente sobre a "reconfiguração da identidade nacional" após dezesseis anos de guerra civil. Logo, a análise das autoras pressupõe um estudo comparativo, englobando a configuração identitária antes do final da guerra. Decerto, minha análise também contempla essa perspectiva por estar inserida no tipo de história que Mia Couto se propõe a contar em seu romance. No entanto, eu argumento que nosso interesse historiográfico pelo autor advém, em parte, de seu reconhecimento literário para além de Moçambique, o qual facilita o acesso aos seus livros aqui no Brasil. 
Justamente por essa facilidade de compra em qualquer livraria brasileira de médio porte, que temos acesso a esse "outro mundo" que Mia Couto suscita em sua obra. Se esse "outro mundo", porém, fosse tão diferente do nosso, ele seria capaz de nos despertar alguma empatia? Segundo o filósofo suíço Alain de Botton (2011, p. 34), no livro Como Proust pode mudar sua vida, essa "comunhão íntima entre nossas próprias vidas e o romance que lemos" torna-se um diferencial na aproximação entre leitor e texto. Marcel Proust exprime que "as pessoas das eras passadas parecem infinitamente distantes de nós. [...] [Todavia] ficamos surpresos ao nos depararmos com um herói homérico cuja emoção é mais ou menos semelhante à que sentimos hoje" (PROUST apud BOTTON 2011, p. 35). Para além da distância temporal, poderíamos incluir a distância espacial. Como um romance moçambicano escrito há vinte anos pode afetar um leitor brasileiro na atualidade? Vejamos um trecho em que Kindzu, após iniciar sua aventura pelo mar, é atormentado pelas intempéries do percurso.

Era justo aquilo? Que mal eu fizera? Ia pondo a vida em recapítulos, havia sim as desvirtudes, bondosas atropelias. Em que vida não figuram? É como não se encontrar pedaço de lenha seca no chão do Inferno. Mas sempre cumpri os comportamentos aconselhados pelos mais velhos. Eu me dedicara a ser filho, aprendedor do meu destino. O barco em que seguia fora abençoado nas devidas cerimónias, eu lhe pusera o nome de meu pai: Taímo. Na primeira viagem, a todos eu premiara com comida e bebida, a gente festejara em cima do barquinho como mandam as tradições. Por que motivo, então, tanta coisa se azarava em meu caminho? No fundo, eu adivinhava a resposta.

- Pai, não me castiga dessa maneira, suspliquei.

À volta, nenhuma resposta. Só as ondas se sucediam, em cada onda o mar se despindo sem nunca chegar à nudez. Eu estava preso naquele infinito. Sempre a água me trouxera facilidades, nela eu ficava no à-vontade de gafanhoto em capinzal. Naqueles momentos, porém, me concorriam confusas desordens. Me vinha vontade de regressar, tornar a alimentar o meu falecido velho, me simplificar no nada acontecer da aldeia (COUTO 2007, p. 43).

Quando nos deparamos com uma situação adversa, não nos questionamos a injustiça de estarmos naquela situação? Não indagamos a nós mesmos o porquê das adversidades? Não nos inquirimos se nossos vícios e pecados seriam tão atrozes que justificassem as dificuldades que enfrentamos? Não nos convencemos em seguida que, a despeito de alguns deslizes que cometemos, procuramos agir corretamente na maioria das vezes? Assim também procede Kindzu ao recapitular os passos de sua vida. Desse modo, nós nos solidarizamos com o personagem porque, aos nossos olhos, suas indagações passam a ser procedentes e seu sofrimento, descabido. Tal qual o rapaz, sentimos o desespero por não encontrarmos respostas, o que nos leva a uma espécie de hesitação: não seria melhor voltar ao que era antes? Inquietações de Kindzu, inquietações nossas.

Devemos, portanto, concordar com Proust: "a emoção é mais ou menos semelhante à que sentimos". No entanto, o fato de nos identificarmos com um jovem moçambicano cujas agruras nos provocam reações parecidas com as dele é insuficiente para situar nosso papel de leitor. Porque as agruras que Kindzu sofre fazem parte do "outro mundo" que Mia Couto nos conta. Esse 
"outro mundo" remete, por sua vez, a uma África que deixou de nos ser completamente desconhecida a partir de um Moçambique próprio do autor. É precisamente aquilo que há de diferente na literatura de Mia Couto que nos atrai: a possibilidade de experienciarmos as dessemelhanças. Mas, curiosamente, essas "dessemelhanças" também devem atender a certas expectativas nossas.

Daí que a África que Mia Couto nos apresenta não nos parece concretamente tangível - parte das vicissitudes de Kindzu residiria, antes, nas possibilidades do onírico. Ao mesmo tempo, como no caso da morte da baleia, subjaz uma crítica social travestida de uma linguagem esteticamente atraente, que mitiga o impacto da crueza da palavra para realçar a cena aterradora pela sobreposição de metáforas. Nesse sentido especificamente, a forma é também conteúdo. Por meio dela, Mia Couto remete às questões sociais e políticas de seu país inserindo o leitor na dimensão humana de seus personagens. É essa dimensão que nos aproxima novamente desse "outro mundo" onde nos solidarizamos enquanto humanidade. Mas se, porventura, esse "outro mundo" se mostrasse semelhante ao nosso, não apenas em emoções, mas em modo de vida, continuaríamos creditando a ele o estatuto da alteridade? Temos um exemplo contado pela escritora nigeriana Chimamanda Adichie (2009), de quando ela estudava em uma universidade americana, em que um professor fez algumas observações sobre o romance que ela havia escrito. Segundo o professor, o problema do romance de Adichie era não ser "autenticamente africano" - isto é, os personagens da autora eram muito parecidos com ele, um homem educado oriundo da classe média. Seus personagens não passavam fome. Eles dirigiam carro. Não, com essas características, eles não podiam ser "autenticamente africanos".

Logo, nós, leitores não africanos, projetamos na literatura originária daquele continente imagens pré-concebidas da África. Ou, no caso do leitor americano, ocorre não apenas uma projeção, mas uma imposição daquilo que ele considera como "legitimamente africano". Michael Chapman (2003, p. 1), professor da área de Literatura na Universidade de KwaZulu-Natal, na África do Sul, diz apropriadamente que deveríamos falar em literaturas africanas, no plural, uma vez que a África está longe de ser homogênea, seja na língua, na cultura, na religião, seja nos processos de inscrição na modernidade. No entanto, lembra-nos o autor, os escritores africanos que ganharam projeção internacional comungam da seguinte característica: seus textos estão sintonizados com as expectativas da crítica literária das universidades britânicas e francesas. Ademais, as editoras de suas obras são multinacionais cujo mercado é principalmente o não africano.

Não atenderia também Mia Couto a esse imperativo? Conforme o autor, "o ser lido é um momento posterior à criação", pois a maioria dos escritores escreve "por razões interiores, que eles próprios desconhecem" (COUTO 2006a). Todavia, é digno de nota que uma das cenas constantes nas primeiras páginas de Terra Sonâmbula corresponda, em parte, ao meu imaginário juvenil sobre o continente, quando Muidinga encontra os cadernos de Kindzu e acende uma fogueira à noite com os papéis não escritos. 
O miúdo se levanta e escolhe entre os papéis, receando rasgar uma folha escrita. Acaba por arrancar a capa de um dos cadernos. Para fazer fogo usa esse papel. Depois se senta ao lado da fogueira, ajeita os cadernos e começa a ler. Balbucia letra a letra, percorrendo o lento desenho de cada uma. Sorri com a satisfação de uma conquista. Vai-se habituando, ganhando despacho.

- Que estás a fazer, rapaz?

- Estou a ler.

- É verdade, já esquecia. Você era capaz ler. Então leia em voz alta que é para me dormecer.

O miúdo lê em voz alta. Seus olhos se abrem mais que a voz que, lenta e cuidadosa, vai decifrando as letras. Ler era coisa que ele apenas agora se recordava saber. O velho Tuahir, ignorante das letras, não Ihe despertara a faculdade da leitura.

A lua parece ter sido chamada pela voz de Muidinga. A noite toda se vai enluarando. Pratinhada, a estrada escuta a estória que desponta dos cadernos: "Quero pôr os tempos..." (COUTO 2007, p. 13-14).

A cena descrita contém elementos que permeiam o imaginário do leitor não africano, como a história contada em torno de uma fogueira sob o céu enluarado. Traz, porém, elementos novos, que mostram sinais dos "novos tempos": a história é narrada a partir de um texto escrito, em que o mais jovem lê em voz alta o caderno para o mais velho. A introdução do universo letrado denotaria a inserção de Moçambique na modernidade, corroborada pelo fato de que, no romance, a criança, aos poucos, recordava-se de que era capaz de ler, ao passo que o velho permanecia "ignorante das letras". No espaço atribuído

Q12 ao papel de contar histórias, Muidinga sobressai-se como o contador de uma história escrita, enquanto Tuahir assume o papel de ouvinte. Desse modo, Mia Couto remodela a imagem pré-concebida que tínhamos de uma sociedade dita "tradicional", em que negligenciávamos possíveis transformações culturais decorrentes do contato com o europeu.

Decerto que as tradições orais têm sido "resgatadas" por antropólogos e linguistas e revalorizadas enquanto "herança literária viva". Assim, Chapman acrescenta que "o desafio de qualquer estética africana é incluir o que o Ocidente ignorou: a herança oral como passado utilizável" (CHAPMAN 2003, p. 5). Mia Couto não a ignora, mas, na passagem citada, ele evidencia esse lado sobre o qual Chimamanda Adichie, de certo modo, falava: a escrita também foi incorporada ao universo africano, mesmo que muitos moçambicanos, por exemplo, ainda não estejam familiarizados com ela.

Quando considerei o papel do leitor na relação entre o escritor e a produção de seu texto literário, eu não havia inicialmente cogitado enveredar por uma "estética da recepção". Contudo, se doto Terra Sonâmbula de um caráter testemunhal, interessa-me saber a que leitor (que aqui substitui o ouvinte) o autor dirige sua narrativa para compreender os meandros da história que ele escreve. Sob a perspectiva do historiador, que não é apenas um leitor, trata-se de uma narrativa que não se iguala à historiografia, mas que concorre para a elaboração de uma versão da história diferente da "história oficial". 


\section{A posição do autor e a inserção da obra no diálogo entre história e literatura}

Decerto pode causar estranheza a um leitor ocidental o fato de um homem branco como Mia Couto, cujos pais eram portugueses, escrever sobre as tradições africanas de seus personagens. Provavelmente concordaríamos com o argumento do autor, que vive em um país majoritariamente negro: "naturalmente na minha cabeça, quando construo um personagem, ele surge negro, porque sou moçambicano" (COUTO 2002). No entanto, também nos questionaríamos: com que propriedade Mia Couto pode construir tais personagens quando ele recebeu uma educação, por assim dizer, europeia, ainda que ele tenha sido criado em um país africano? Porque sabemos da hierarquização do espaço colonial - dos ambientes frequentados pelos brancos que os negros não frequentavam. Sabemos que Mia Couto cresceu quando Moçambique ainda era colônia de Portugal. E sabemos também que mesmo aqueles moçambicanos negros que passaram do estatuto de indígena para assimilado - e que passaram a gozar, portanto, dos mesmos direitos e deveres dos portugueses - continuavam a ser considerados, pelos colonos, não como "um de nós" (como um branco), mas "como o mais civilizado deles" (como o mais civilizado dentre os negros) (CABAÇO 2007).

No entanto, Couto, assim como seus pais e irmãos, procurava distanciar-se daquele ambiente racista. A Beira, cidade onde ele nasceu e viveu até o início dos anos 70, tinha uma lógica de ocupação territorial diferente das outras cidades moçambicanas pelo fato de a cidade ter nascido em um pântano, segundo o autor. Assim, os negros não viviam para além dos subúrbios, e sim do outro lado da rua onde morava sua família (COUTO 2009b). O contato com a população local dava-se também dentro de casa, quando o então adolescente ouvia as emissões da FRELIMO em cumplicidade com os empregados. Depois, quando já estudante de Medicina em Maputo (então Lourenço Marques), ele resolveu abraçar a causa da independência do país. Ao iniciar a militância na FRELIMO, abandonou os estudos para tornar-se jornalista de modo a difundir a causa revolucionária, atividade que se estenderia por onze anos (de 1974 a 1985). Apenas nesse ano, em 85, ele voltaria a frequentar a universidade, mas trocaria a Medicina pela Biologia.

Pois bem, devido ao trabalho desenvolvido como jornalista, Mia Couto percorreu muito do interior do país, recolhendo histórias daquelas vozes rurais, as quais resultaram em seu primeiro livro de contos, Vozes Anoitecidas, publicado em 1985 (COUTO 2006b). O autor, então, passou a identificar-se com essas vozes, com as vítimas da guerra e, de certa forma, passou a dar-Ihes voz em sua literatura. É certo que houve "distribuição desigual dos sofrimentos" durante a guerra, como nos recorda o antropólogo e historiador Omar Ribeiro Thomaz (2005/2006), já que uma minoria demográfica "aparentemente privilegiada", como os brancos, não pegou em armas. Ainda assim, Mia Couto, mesmo sendo um ex-militante da FRELIMO que permaneceu desarmado e razoavelmente protegido de uma "ameaça física evidente" por habitar a zona urbana, não dá voz a nenhuma das partes envolvidas diretamente no conflito, mas, sim, àqueles que teriam sido duramente atingidos pela guerra. É com eles, portanto, que Couto se solidariza. É a partir deles que o autor constrói a africanidade em 
sua literatura. Mas tomemos cuidado: "o escritor é um construtor de mundos inventados", como alerta Couto. Não é pelo fato de ele ser branco que ele não pode construir personagens negros, assim como não é pelo fato de ele ser homem que ele não pode escrever sobre as mulheres, por exemplo (COUTO 2002). Ademais, Couto considera que, mesmo os escritores negros em ascensão no universo literário moçambicano, "são mulatos do ponto de vista cultural, são todos eles urbanos, nasceram na língua portuguesa já, é raro o que sabe (sic) falar uma língua que não seja o português". O autor não se sente, portanto, "um representante da raça branca", mas, sim, "um mulato culturalmente" (COUTO 2002). Daí que, por vezes, Mia Couto escreve sua versão da história a partir de três tendências interligadas em Terra Sonâmbula, a saber: (i) o dever de memória; (ii) a construção de uma africanidade; e (iii) a perspectiva do futuro, na qual me deterei.

Por dever de memória, recorro ao filósofo francês Paul Ricoeur (2007 p. 101) para definir o termo, que compreende o "dever de fazer justiça, pela lembrança, a um outro que não a si". Para tanto, Mia Couto opta por contar a pequena história, que ele julga ter sido excluída da História (com " $h$ " maiúsculo) que conhecemos, a qual serviria aos interesses das elites (COUTO 2006a). Os personagens principais de Terra Sonâmbula são, assim, meninos muito jovens, que, por uma razão ou outra, tiveram de abandonar sua terra de origem - a terra de seus antepassados - e buscar um novo rumo em um país devastado pela guerra. Em outros tempos, residiria nesses jovens a expectativa de futuro 214 da nação. Mas, em plena guerra, que futuro poderia ser esse à medida que um menino é desprovido de memória, enquanto outro abandona aquilo que se constituía como vínculo com os antepassados? Pelas palavras de Kindzu,

\begin{abstract}
A guerra crescia e tirava dali a maior parte dos habitantes. Mesmo na vila, sede do distrito, as casas de cimento estavam agora vazias. As paredes, cheias de buracos de balas, semelhavam a pele de um leproso. Os bandos disparavam contra as casas como se elas Ihes trouxessem raiva. Quem sabe alvejassem não as casas mas o tempo, esse tempo que trouxera o cimento e as residências que duravam mais que a vida dos homens. Nas ruas cresciam arbustos, pelas janelas espreitavam capins. Parecia o mato vinha agora buscar terrenos de que tinha sido exclusivo dono. Sempre me tinham dito que a vila estava de pé por licença de poderes antigos, poderes vindos do longe. Quem constrói a casa não é quem a ergueu mas quem nela mora. E agora, sem residentes, as casas de cimento apodreciam como a carcaça que se tira a um animal (COUTO 2007, p. 23).
\end{abstract}

Notemos, primeiramente, uma herança do colonialismo, a que Mia Couto remeterá em seu quarto romance, Vinte e Zinco (1999), dando voz à adivinhadora Jessumina: "Vinte e cinco é para vocês que vivem no bairro de cimento. Para nós, negros pobres que vivemos na madeira e zinco, o nosso dia ainda está por vir" (COUTO 1999, p. 11). Não vou me ater aqui à diferença de significados para o povo moçambicano entre o dia 25 de abril de 1974, quando foi deflagrada a Revolução dos Cravos em Portugal, e o 25 de junho de 1975, dia da independência de Moçambique. Interessa-me a antiga cisão social que alijava "os negros em bairros de caniço, reservando à elite branca 
os confortáveis casarões dos bairros de asfalto" (SECCO 1999, p. 112). Daí a importância atribuída por Kindzu ao fato de se encontrarem vazias as casas de cimento, construídas na sede do distrito. É como se nem elas - dada a antiga estrutura de poder que, de certa forma, encarnavam - estivessem imunes às vicissitudes da guerra. Por esse motivo, o personagem acrescenta que os bandos atiravam nas casas como "se elas Ihes trouxessem raiva", entrevendo aí que as casas representariam a fúria dos bandos contra o tempo - "esse tempo que trouxera o cimento e as residências que duravam mais que a vida dos homens". Ainda assim, a despeito da história inscrita nessas casas e de sua resistência material, elas não estavam imunes à ação da guerra, que acelerou, por sua vez, sua deterioração. Não foi diretamente a ação das balas que fez com que as casas apodrecessem como "carcaças", mas, sim, o fato de que os tiroteios afugentavam as famílias, e elas, por sua vez, abandonavam as casas.

Mia Couto imbui Kindzu de certa sabedoria africana quando o personagem analisa a situação a partir da rememoração de dizeres que ele outrora escutara: "Sempre me tinham dito que a vila estava de pé por licença de poderes antigos, poderes vindos do longe". Para ele, naquele momento, os antigos saberes adquiriam sentido porque explicavam o porquê de os arbustos ocuparem as casas e as ruas antes ocupadas por gente. Afinal, "quem constrói a casa não é quem a ergueu, mas quem nela mora". Nesse sentido, quando Kindzu recorre à africanidade projetada pelo autor, ele estabelece uma ponte entre o passado e o presente. O futuro da nação residiria no reconhecimento de que a identidade nacional moçambicana pressuporia o conhecimento de seu próprio passado, de sua própria história - de "poderes antigos" que pautam a vida dos homens.

Nas páginas finais do romance, Kindzu sonha que está se transformando em um naparama, mas, antes da transformação, ele ouve as palavras proferidas por um feiticeiro sobre um futuro aterrador:

Chorais pelos dias de hoje? Pois saibam que os dias que virão serão ainda piores. Foi por isso que fizeram esta guerra, para envenenar o ventre do tempo, para que o presente parisse monstros no lugar da esperança. Não mais procureis vossos familiares que saíram para outras terras em busca da paz. Mesmo que os reencontreis eles não vos reconhecerão. Vós vos convertêsteis em bichos, sem família, sem nação. Porque esta guerra não foi feita para vos tirar do país mas para tirar o país de dentro de vós (COUTO 2007, p. 200-201).

Precisamente a perda do vínculo com a família, com a terra, com o país transforma os humanos em bichos porque os sentimentos mais profundos que nos ligariam enquanto humanidade são dispersos pela guerra. Mia Couto opta, então, em escrever uma história do tempo presente, em que ele situa o presentismo como sintoma da crise desse tempo. Aparentemente não haveria esperança de futuro, a não ser que fôssemos "capazes de nos despirmos deste tempo que nos fez animais".

No final, porém, restará uma manhã como esta, cheia de luz nova e se escutará uma voz longínqua como se fosse uma memória de antes 
de sermos gente. E surgirão os doces acordes de uma canção, o terno embalo da primeira mãe. Esse canto, sim, será nosso, a lembrança de uma raiz funda que não foram capazes de nos arrancar. Essa voz nos dará a força de um novo princípio e, ao escutá-la, os cadáveres sossegarão nas covas e os sobreviventes abraçarão a vida com o ingénuo entusiasmo dos namorados. Tudo isso se fará se formos capazes de nos despirmos deste tempo que nos fez animais. Aceitemos morrer como gente que já não somos. Deixai que morra o animal em que esta guerra nos converteu (COUTO 2007, p. 201-202).

No sonho de Kindzu, a fala do feiticeiro provoca nas pessoas que o escutavam "o mais extraordinário dos fenómenos": as gentes que ali estavam reunidas vão perdendo "as humanas dimensões" e se transfigurando "em bicharada" (COUTO 2007, p. 202). Elas se convertem naquilo que o tempo presente, em geral, fazia com as pessoas, levando-as à perda não apenas das feições, mas também do próprio verbo. Era necessário, portanto, um novo princípio que transformasse os bichos em gente novamente. Mas como isso aconteceria? Decerto, o "terno embalo da primeira mãe" indica algo que precede nosso conhecimento adquirido. Todavia, o que seria isso que nos precede e que, ao mesmo tempo, nos transcende, que está entranhado como uma "raiz funda que não foram capazes de nos arrancar"? Quando Kindzu, ainda em sonho, encontra seu irmão, Junhito, que havia se transformado em galo, ocorre-lhe que o caçula precisasse de "um pouco de infância". Para isso, Kindzu recorre ao "terno embalo" de "nossa mãe" e entoa o acorde materno para o irmão, que volta a se transformar em gente.

216 sua "última ponte com a família" é o que possibilita ao caçula humanizar-se novamente. Nesse sentido, Mia Couto haveria de dizer, dezessete anos depois, que a literatura ajuda a "manter vivo o desejo de inventar outra história para uma nação e outra utopia como saída" (COUTO 2009a, p. 6). Com efeito, ele recorre a utopias tangíveis em Terra Sonâmbula e projeta a expectativa de um novo princípio para Moçambique em uma história por ser escrita.

Eu gostaria, dessa forma, de finalizar este artigo, retomando e reforçando certos questionamentos. O primeiro é que estou longe aqui de encarar a literatura como documento, tal qual a pretensão de quarenta anos atrás do professor de Estudos Americanos R. Gordon Kelly, para quem "os documentos literários podiam ser utilizados como evidência histórica" (KELLY 1974, p. 146). Logo, não tenho a pretensão de reconstituir a história recente de Moçambique a partir do romance de Mia Couto. Ao contrário, interessa-me saber de que modo o escritor moçambicano relaciona-se com a história de seu país ao escrevê-la sob um viés literário que lhe é próprio. A história da guerra que ele escreve em seu romance aponta para um compromisso com a "pequena história", como se o romance pudesse restituir a voz àqueles que teriam sido silenciados. Sua versão da história aponta, especialmente, para uma valorização da africanidade a partir do respeito aos ancestrais e às tradições. Esse respeito implicaria, de certa forma, uma recuperação do sentido de humanidade, em que residiria a esperança de um futuro para o país. O segundo questionamento resvala para "o perigo da história única" (the danger of a single story) a que se refere Chimamanda Adichie, pois tendo o romance de Mia Couto caído nas graças da crítica literária europeia, ele 
parece corresponder às expectativas não africanas daquilo que é considerado "autenticamente africano". Por fim, o terceiro questionamento merece ser reproduzido em forma de pergunta: Por que tantas vezes ignoramos a dimensão humana dos personagens literários em nossas abordagens historiográficas quando precisamente a história também se constitui de tal dimensão? Nesse sentido, Mia Couto, enquanto romancista, lembra-nos (aqui incluo os historiadores) de que a história, afinal, é feita pelos homens.

\section{Referências bibliográficas}

ADICHIE, Chimamanda Ngozi. The danger of a single story. TED Ideas Worth Spreading, 2009. Disponível em: http://www.ted.com/talks/lang/pt/ chimamanda_adichie_the_danger_of_a_single_story.html. Acesso em 26/01/2013.

ANDERSON, Benedict. Comunidades imaginadas. São Paulo: Companhia das Letras, 2008.

BOTTON, Alain de. Como Proust pode mudar sua vida. Rio de Janeiro: Intrínseca, 2011.

CABAÇO, José Luís de Oliveira. Moçambique: identidades, colonialismo e libertação. Tese (Doutorado). Programa de Pós-Graduação em Antropologia Social da Universidade de São Paulo, São Paulo, 2007.

CAMPOS, Josilene Silva. As representações da guerra civil e a construção da nação moçambicana nos romances de Mia Couto (1992-2000). Dissertação (Mestrado). Programa de Pós-Graduação em História da Universidade Federal de Goiás, Goiânia, 2009.

CHAPMAN, Michael. African Literature, African Literatures: Cultural Practice or Art Practice? Research in African Literatures, v. 34, n. 1, p. 1-10, 2003.

COUTO, Mia. O coração de Moçambique. Entrevista concedida a Irinêo Netto. Caderno G, Gazeta do Povo, 25/06/2006a. Disponível em: http://www. gazetadopovo.com.br/cadernog/conteudo. phtml?tl=1\&id=575902\&tit=0 coracao-de-mocambique. Acesso em: 30/01/2013.

Mia Couto e o exercício da humildade. Entrevista concedida à Marilene Felinto. Mundo, Folha de São Paulo, 21/07/2002. Disponível em: http:// www.macua.org/miacouto/MiaCoutoexerciciodahumildade.htm. Acesso em: 30/01/2013.

. Mia Couto, o poeta que escreve histórias. Entrevista concedida a Mirian Sanger. Revista da Cultura, n. 19, p. 4-6, 2009a.

. Mia Couto. Nova África. Programa da TV Brasil, 06/2009b. Disponível em: http://tvbrasil.ebc.com.br/novaafrica/2010/01/31/mia-couto-falasobre-africa-mocambique-beira-e-literatura. Acesso em: 22/02/2012.

- Mia Couto revisitado. Entrevista concedida à Elisa Andrade Buzzo. Digestivo Cultural, 14/09/2006b. Disponível em: http://www. 
digestivocultural.com/colunistas/coluna.asp?codigo $=2047 \&$ titulo $=$ Mia Couto_revisitado. Acesso em: 30/01/2013.

. Terra Sonâmbula. São Paulo: Companhia das Letras, 2007.

Vinte e Zinco. Lisboa: Ed. Caminho, 1999.

GRAYBILL, Lyn S. Pardon, Punishment, and Amnesia: Three African Post-Conflict Methods. Third World Quarterly, v. 25, n. 6, p. 1117-1130, 2004.

KELLY, R. Gordon. Literature and the historian. American Quarterly, v. 26, n. 2, p. 141-159, 1974.

NEWITT, Malyn. A History of Mozambique. Bloomington/Indianopolis: Indiana University Press, 1995.

RIBEIRO, Milton. 50 livros para morrer antes de ler. Sul 21, 26/01/2013. Disponível em: http://www.sul21.com.br/jornal/2013/01/50-livros-paramorrer-antes-de-ler. Acesso em: 26/01/2013.

RICOEUR, Paul. A memória, a história, o esquecimento. Campinas: Editora da Unicamp, 2007.

SECCO, Carmen Lúcia Tindó Ribeiro. Alegorias em abril: Moçambique e o sonho de um outro vinte e cinco (uma leitura do romance Vinte e Zinco, do escritor Mia Couto). Via Atlântica, n. 3, p. 110-123, 1999.

SELIGMANN-SILVA, Márcio. Narrar o trauma: a questão dos testemunhos de catástrofes históricas. Psicologia Clínica, v. 20, n. 1, p. 65-82, 2008.

TEDESCO, Maria do Carmo Ferraz. Narrativas da moçambicanidade: os romances de Paulina Chiziane e Mia Couto e a reconfiguração da identidade nacional. Tese (Doutorado). Programa de Pós-Graduação em História da Universidade de Brasília, Brasília, 2008.

THOMAZ, Omar Ribeiro. "Raça", nação e status: histórias de guerra e "relações raciais" em Moçambique. Revista USP, n. 68, p. 252-268, 2005-2006.

WILSON, K. B. Cults of violence and counter-violence in Mozambique. Journal of Southern African Studies, v. 18, n. 3, p. 527-582, 1992. 